УДК: 378.04:796.83.071.4

(C) Хижняк O.O., 2019 p.

http://orcid.org./0000-0003-1791-2957

DOI: $10.34142 / 23128046.2019 .47 .14$

О. О. Хижняк

\title{
ПРАКТИКО-ОРІСНТОВАНИЙ ПІДХІД У СИСТЕМІ ПРОФЕСІЙНОЇ ПІДГОТОВКИ ТРЕНЕРА 3 БОКСУ У ЗАКЛАДАХ ВИЩОЇ ОСВІТИ
}

У статті обтрунтовано перспективи застосування практикоорієнтованого підходу в системі професійної підготовки тренера з боксу в закладах вищої освіти. Проблема забезпечення якості підготовки майбутніх тренерів з боксу та їх подальшого успішного працевлаштування робить актуальною орієнтацією закладів вищої освіти на здатність їх випускників до практичної реалізації надбаних компетенцій та ставить питання про доцільність розробки механізму взаємодії університету $i$ потенційних роботодавиів, якими в типових випадках є спортивні школи різного типу.

Встановлено, щзо практико-орієнтований підхід спрямований на надбання не тільки знань, але ци умінь, навичок $i$ досвіду практичної діяльності. Аналіз комплексу літературних джерел дозволив установити, що досить часто практико-орієнтований підхід дослідники розглядають як метод викладання $і$ навчання в поєднанні з практичною діяльністю, орієнтацією навчального прочесу на кінцевий продукт навчання формування і розвиток професійних компетенцій.

Нові технології підготовки майбутнього тренера можуть розроблятися на основі практико-орієнтованого підходу, що підвищить вмотивованість студентів до успішного формування власної професійної компетентності. Практико-орієнтований підхід - ие метод підготовки майбутнього тренера, щзо дозволяє студентам поєднувати навчання у вищому закладі освіти з практичною роботою. У статті встановлено, щзо практико-орієнтований підхід реалізовується за допомогою розробленої моделі, щуо включає иільовий, змістовий та технологічний компоненти.

Практико-орієнтований підхід у дослідженні визначається одним із найефективніших засобів професіоналізаиії підготовки тренера з боксу, оскільки максимально наближує студентів до майбутньої професійной діяльності. Його сутність полягає в організації навчального процесу в контексті майбутньої професії шляхом відтворення у формах $i$ методах навчальної діяльності студентів реальних психолого-сочіальних ситуацій, щуо супроводжують професійну діяльність тренера.

Ключові слова: практико-орієнтований підхід, спортивно-педагогічна освіта, майбутній тренер з боксу, професійна підготовка тренера. 
Khyzhniak O. O. Practical-oriented approach in the system of the boxing coach vocational training in higher educational institutions. The article justifies potentials of practical-oriented approach application in the system of the boxing coach vocational training in higher educational institutions.

The quality problem of training of the future boxing coach training and their further successful employment makes the current focus of higher educational institutions on the ability of their graduates to realizethe acquired competences in practical way and raises the question of developmentexpediency of interaction mechanism between the university and potential employers, which in typical cases are sports schools of different types.

It is established that the practical-oriented approach is focused not only on acquisition of knowledge, but also skills and experience of practical activities. The analysis of literature source set has allowed to establish that quite often the practical-oriented approachis consider by researchers as a teaching and studymethod in combination with practical activities, and orientations of educational process at the end of studying are formation and development of professional competences. New technologies of the future coach training can be developed on a basis of the practical-oriented approach which will raise students motivation to successful formation of their own professional competence.

Practical-oriented approach is a method of the future coach training, which allows students to combine studyingin the higher educational institution with practical work. Future specialists are put in a real working environment where they receive the appropriate practical and social skills necessary for successful coaching. It is established that the practical-oriented approach is realizedthrough the developed model which includes target, substantive and technology components.

The practical-oriented approach in the research is determined by one of the most effective professional ways of boxing coach training, as it makes students as close as possible to the future professional activity. The point is in the organization of educational process in the context of future profession by reconstruction of realpsycho-socialsituations in forms and methods of educational students' activity which take place in professional coach activity.

Keywords: practical-oriented approach, sports pedagogical education, future boxing coach, vocational coach training.

Вступ. У сучасних умовах інтеграції освіти України в європейський простір заклади вищої освіти мають забезпечити таку якість професійної підготовки, яка забезпечує готовність випускників до практичної реалізації надбаних компетентностей.

У більшості наукових досліджень практико-орієнтований підхід розглядається в контексті підготовки фахівців у системі вищої освіти. У той же час вважаємо актуальним застосування цього підходу в системі 
підготовки тренерів у закладах вищої освіти, які надають освітні послуги за спеціальністю 017 «Фізична культура і спорт».

Практико-орієнтований підхід став предметом дослідження вітчизняних і зарубіжних учених (Р. Аджимулаєв, Н. Басалаєва, С. Бобраков, А. Вербицький, Н. Житнік, С. Коп’єва, Н. Матюшенко, І І. Пальчикова, А. Пригодій), однак застосування положень досліджуваного підходу у системі професійної підготовки тренера з боксу не знаходило належного висвітлення.

Аналіз роботи тренерів з боксу в ДЮСШ м. Полтави, специфіки проходження практик студентами спеціальності 017 «Фізична культура і спорт» засвідчила, що головною проблемою традиційної моделі підготовки майбутнього тренера $\epsilon$ відрив теоретичної підготовки від майбутньої професійної діяльності.

Мета та завдання. Проаналізувати особливості застосування практикоорієнтованого підходу в системі професійної підготовки тренера 3 боксу в сучасних закладах вищої освіти України.

Методи дослідження: теоретичний аналіз науково-педагогічної літератури, узагальнення й систематизація інформації про професійну підготовку тренерів з боксу, анкетування викладачів, тренерів ДЮСШ, студентів спеціальності 017 «Фізична культура і спорт».

Результати. Вивчення праць вітчизняних дослідників дозволило констатувати, що сучасна система вищої освіти (в тому числі і підготовка тренера) є надмірно «теоретизованою», оскільки цикл фахової підготовки переважає над практико-методичним. При цьому, як зазначає С. Бобраков, спостерігається недостатній зв'язок між теоретичними i практичними елементами процесу навчання: теорія не має впливу на практичну діяльність, практична діяльність не відповідає реаліям професійної діяльності (Bobrakov,2012).

Часто практико-орієнтований підхід дослідники розглядають як метод викладання і навчання в поєднанні з практичною діяльністю, орієнтації навчального процесу на кінцевий продукт навчання - формування і розвиток професійних компетенцій (Bakhmetova, 2012).

Практико-орієнтований підхід у дослідженнях німецьких учених трактується: як активна форма організації професійної підготовки, призначена для застосування в теоретичному та практичному компонентах, що реалізується за допомогою насичення навчального процесу елементами професійної діяльності (Warnek, 2007); як орієнтація змісту і методів педагогічного процесу на формування у майбутніх фахівців практичних навичок роботи (Post, 2010); як система навчальних проблемних ситуацій, 
методичних та ситуаційних завдань, спроектованих у професійну підготовку фахівців (Pietsch, 2010).

Практико-орієнтований підхід розглядається також як метод викладання i навчання в поєднанні 3 практичною діяльністю 3 метою орієнтації навчального процесу на кінцевий продукт професійної підготовки - формування і розвиток компетенцій (Obraztsov,2003).

Л. Петренко, узагальнюючи дослідження вітчизняних педагогів, зазначає, що зараз не існує чіткого розуміння педагогічної сутності практикоорієнтованого підходу. Автор визначає такі тлумачення: формування професійного досвіду студентів у процесі занурення в професійне середовище під час виробничої і переддипломної практики; професійноорієнтовані технології навчання, спрямовані на формування в майбутніх фахівців значущих для професійної діяльності знань, умінь, навичок, професійно-важливих якостей; формування професійно і соціально значущих компетенцій в ході надбання студентами знань, умінь, навичок і досвіду діяльності тощо (Petrenko,2016).

Практико-орієнтований підхід дозволяє моделювати предметний зміст професійної діяльності, тим самим забезпечуючи умови трансформації навчальної діяльності студента у професійну діяльність фахівця (Maikovska, 2016).

Практико-орієнтований підхід грунтується на оволодінні майбутнім тренером предметним знанням у процесі практичної діяльності. При цьому практико-орієнтований, навчально-виховний i навчально-тренувальний процеси трактуються як спільна діяльність студента та викладача, що орієнтована на практичний досвід майбутнього тренера, формування у нього навичок для професійної самореалізації.

Практико-орієнтований підхід до підготовки тренера з боксу в закладах вищої освіти спрямований на формування практичних умінь i навичок студентів, забезпечення зв'язку між теоретичними знаннями та реальною професійною діяльністю тренера.

Для досягнення завдань практико-орієнтованого підходу в системі підготовки майбутнього тренера з боксу вважаємо за необхідне визначити систему принципів:

- принцип використання практико-орієнтованих завдань у навчальновиховному і навчально-тренувальному процесі;

- принцип пріоритетності практичної підготовки, орієнтація завдань навчальних дисциплін на систему навчальних практик; 
- принцип доступності матеріалу практико-орієнтованих завдань в процесі навчальних практик;

- принцип диференціації та індивідуалізації навчально-тренувального процесу;

- принцип інтеграції навчального матеріалу 3 орієнтацією на завдання майбутньої професійної діяльності тренера з боксу;

- принцип забезпечення гнучкості і динамічності оновлення освітньопрофесійних програм підготовки фахівців за спеціальністю 017 Фізична культура і спорт;

- принцип використання сучасних форм і методів роботи зі студентами майбутніми тренерами з боксу;

- принцип рефлексії як інструмента сприйняття досвіду діяльності для подальшого професійного розвитку тренера.

Зміст практико-орієнтованої професійної підготовки тренера з боксу у сучасному закладі вищої освіти включає: теоретичний блок (лекції, семінари, самостійну та індивідуальну роботу, курсове проектування тощо); практичний блок (практичні та лабораторні роботи, тренувальні заняття, участь у змаганнях різного рівня, навчальну i виробничу практики, виконання дослідних проектів у межах наукової роботи кафедри, студентського наукового гуртка, участь у круглих столах із стейкхолдерами).

Визначаючи функції практико-орієнтованого підходу, вважаємо за доречне навести класифікацію Т. Бондаренко, що включає:

- діагностичну функцію як визначення мотивації навчання студентів;

- освітню функцію, що припускає використання всієї сукупності наявних ресурсів закладу вищої освіти для закріплення у студентів певних загальнокультурних і професійних компетенцій як основної мети практикоорієнтованого навчання;

- розвиваючу функцію, спрямовану на розвиток i актуалізацію професійно значимих якостей студентів, на самостійне набуття нових знань i вмінь;

- інтегруючу функцію, яка полягає в досягненні синергетичного ефекту від одержання, обробки й систематизації накопичених студентами знань, умінь (Bondarenko, 2013).

Практико-орієнтований підхід спрямовує навчальний процес 3 підготовки майбутніх тренерів не лише на формування традиційно знань, умінь і навичок, але, насамперед, досвіду практичної діяльності, що досягається через формування професійної компетентності (Yalalov, 2008). 
Це актуалізує взаємозв'язок між практико-орієнтованим, компетентнісним, діяльнісним і особистісним підходами.

Моделювання реальних професійних ситуацій у закладах вищої освіти, що готують майбутніх тренерів з боксу на основі впровадження практикоорієнтованого підходу досягається шляхом перерозподілу теоретичного, практичного та методичного складника професійної підготовки.

Практико-орієнтований підхід у професійній підготовці майбутніх тренерів 3 боксу передбачає перенесення акценту на практику, що трансформує навчальну діяльність студентів в особистісно значущу, створює позитивну мотивацію до майбутньої професійної діяльності.

У професійній підготовці майбутнього тренера 3 боксу система навчальних практик має бути середовищем, у якому відбувається професійна майстерність, здійснюється суб'єкт-суб'єктна взаємодія, формується система ціннісних орієнтацій.

Аналіз навчальних планів підготовки тренерів дозволяє констатувати, що система практичної підготовки у закладах вищої освіти має наскрізний характер, при цьому проходження різних видів практик здійснюється протягом всього періоду навчання на першому (бакалаврському) і другому (магістерському) рівнях.

Структура практичної підготовки тренерів за спеціальністю 017 Фізична культура і спорт наведена на рис 1.

Кожен вид практики має свої завдання, структуру, вимоги та визначені види діяльності. Загальна ж мета практики полягає у формуванні умінь i навичок застосувати теоретичні знання для відбору і орієнтації спортсменів, використовувати основи моделювання та прогнозування у підготовці спортсменів, успішного забезпечення навчально-тренувального процесу, організації фізкультурно-оздоровчих та спортивних заходів. 


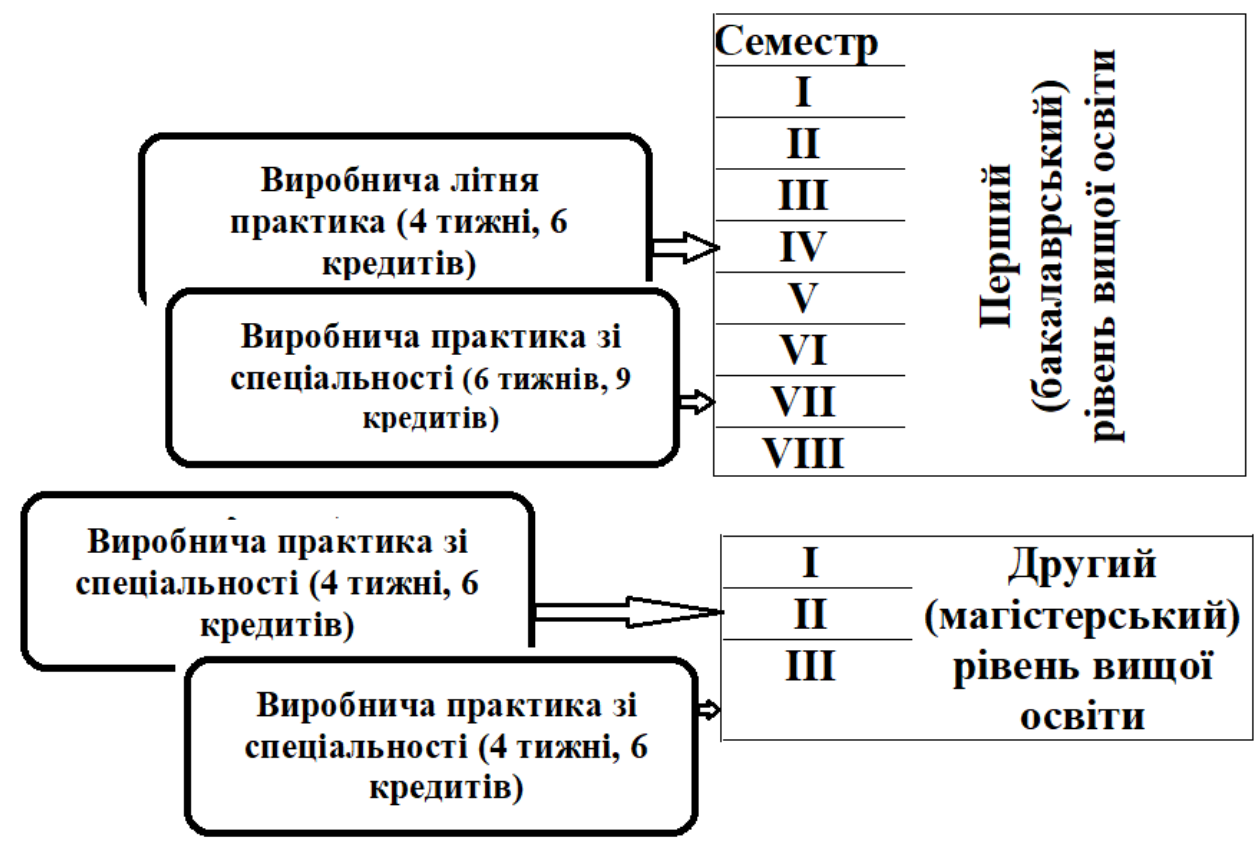

Рис. 1. Структура практичної підготовки фахівців за спеціальністю 017 Фізична культура і спорт

Визначена мета реалізовується через вирішення наступних завдань: сприяння формуванню основних професійно-педагогічних навичок та умінь, необхідних для майбутньої роботи тренера з боксу; ознайомлення студентів зі структурою і змістом роботи спортивної школи і навчально-тренувальних груп з боксу; створення цілісного уявлення про зміст і характер діяльності керівника спортивної школи, тренера 3 конкретного виду спорту (організаційна, виховна, навчально-спортивна, науково-дослідна, адміністративно-господарча, суддівська та представницька); формування стійких навичок 3 організації, планування та проведення навчальнотренувального процесу в спортивних групах з боксу, а також контролю за його ефективністю; усвідомлення застосованих педагогічних технологій та окремих методик планування, організації й контролю діяльності тренера 3 боксу на основі вивчення нормативної, організаційно-методичної та фінансової документації (Holub, 2018).

Обговорення. Проведене дослідження підтверджує результати навчально-методичних упроваджень вітчизняних і зарубіжних учених щодо особливостей застосування практико-орієнтованого підходу в системі професійної підготовки тренера з боксу в сучасних закладах вищої освіти України, а саме: а) застосування практико-орієнтованого підходу підвищує вмотивованість студентів до формування власної професійної компетентності; б) практико-орієнтований підхід дозволяє студентам поєднувати навчання у закладі вищої освіти з практичною роботою; в) практико-орієнтований підхід $\epsilon$ ефективним засобом професіоналізації підготовки тренера з боксу, оскільки максимально наближує студентів до майбутньої професійної діяльності; 
г) реалізація практичної спрямованості навчально-тренувального процесу здійснюється через систему навчальних практик, які $\epsilon$ головним системотворчим ядром підготовки тренера у ЗВО.

Висновки. Отже, головною метою професійної підготовки тренера 3 боксу є розвиток загальних і професійних компетентностей, здатності діяти в проблемних ситуаціях, використовуючи отримані теоретичні знання, вміння, навички і особистісний досвід у майбутній професійній діяльності. Ознаками практико-орієнтованого підходу визначаємо: орієнтацію навчальних програм на вимоги ринку праці; реальну практичну спрямованість курсових робіт i дослідницьких проектів; активне залучення фахівців-практиків до навчальнотренувального процесу факультету фізичного виховання. Перспективи подальших досліджень вбачаємо в розробці цілісної інтегрованої системи професійної підготовки майбутнього тренера на засадах практикоорієнтованого підходу.

Бахметова Ю.Н. Реализация практико-ориентированного подхода в процессе формирования методической культуры будущих педагогов-психологов в профессиональном обучении. Вестник Майкопского государственного университета. 2012. № 4. С. 112-116.

Бобраков С. Реформування змісту професійної підготовки вчителів у ВНЗ Німеччини: практико-орієнтований підхід. Порівняльна професійна педагогіка. 2012. № 2. С. 161-168.

Бондаренко Т.Н. Функциональная модель эффективного практико-ориентированного обучения в высшем учебном заведении. Интернет-журнал «Науковедение». 2013. №4.

Голуб Л. О. Наскрізна програма практики студентів II та IV курсів I рівня освіти факультету фізичного виховання денної форми навчання. Галузь знань 01 Освіта за спеціальністю за спеціальністю 017. Фізична культура і спорт. Полтава. 2018. 16 с.

Майковська В. І. Практико-орієнтоване навчання як засіб професіоналізації підготовки майбутніх фахівців в Україні. Проблеми інженерно-педагогічної освіти. 2016. № 50-51. С. 161-167.

Образцов П. И. Проектирование и конструирование профессионально-ориентированной технологии обучения. Орел : ОГУ. 2003.94 с.

Петренко Л.М.Практико-орієнтований підхід до формування змісту підвищення кваліфікації педагогів за дистанційною формою. Методичні засади підвищення кваліфікації педагогічних працівників системи професійної освіти: збірник матеріалів Всеукраїнської Інтернет-конференції. Хмельницький. 2016. С. 465-469.

Ялалов Ф. Деятельностно-компетентностный подход к практикоориентированному образованию. Высшее образование в России. 2008. № 1. С. 89-93.

Pietsch S. Begleiten und begleitet werden. Praxisnahe Fallarbeit - ein Beitrag zur Professionalisierung in der universitären Lehrerbildung. Kassel : Kassel University Press. 2010. $294 \mathrm{~s}$.

Post E.-M. Der Einsatz von handlungs-, erfahrungs- und erlebnisorientierten Methoden in der Lehrerinnen- und Lehrerfortbildung von pädagogischen Führungskräften zur Initiierung von Lernen. Studien zur Verknüpfung von Erfahrung, Reflexion und Transfer. Leipzig : Univ. Dass. 2010. $791 \mathrm{~s}$. 
Warnek D. Aktionsforschung und Praxisbezug in der Darf-Lehrerausbildung. Dagmara Warneke. Kassel : Kassel Univ. Press, 2007. 599 s.

\section{REFERENCES:}

Bahmetova, Ju. N. (2012). Realizacija praktiko-orientirovannogo podhoda $\mathrm{v}$ processe formirovanija metodicheskoj kul'tury budushhih pedagogov-psihologov $\mathrm{v}$ professional'nom obuchenii. [The implementation of a practice-oriented approach in the process of forming a methodological culture of future teachers-psychologists in vocational training]. Vestnik Majkopskogo gosudarstvennogo universiteta. № 4. S. 112116. (in Russian).

Bobrakov, S. (2012). Reformuvannia zmistu profesiinoi pidhotovky vchyteliv u vnz nimechchyny: praktyko-oriientovanyi pidkhid. [Reforming the Content of Teacher Training in German Universities: A Practically Oriented Approach] Porivnialna profesiina pedahohika. № 2. S. 161-168. (in Ukranian).

Bondarenko, T. N. (2013). Funkcional'naja model' jeffektivnogo praktiko-orientirovannogo obuchenija $\mathrm{v}$ vysshem uchebnom zavedenii. [Functional model of effective practiceoriented education in higher education]. Internet-zhurnal «Naukovedenie». №4. (in Russian).

Holub, L. O. (2018). Naskrizna prohrama praktyky studentiv II ta IV kursiv I rivnia osvity fakultetu fizychnoho vykhovannia dennoi formy navchannia. Haluz znan 01 Osvita za spetsialnistiu za spetsialnistiu 017. Fizychna kultura i sport. [Program of practice for students of II and IV courses of I level of education of the faculty of physical education of full-time education. Area of Knowledge 01 Specialty Education Specialty 017. Physical Education and Sports]. Poltava. 16 s. (in Ukranian).

Jalalov, F. (2008). Dejatel'nostno-kompetentnostnyj podhod k praktikoorientirovannomu obrazovaniju. [Competency-based approach to practice-oriented education]. Vysshee obrazovanie v Rossii. № 1. S. 89-93. (in Russian).

Maikovska, V. I. (2016). Praktyko-oriientovane navchannia yak zasib profesionalizatsii pidhotovky maibutnikh fakhivtsiv v Ukraini. [Practice-oriented training as a means of professionalizing the training of future specialists in Ukraine]. Problemy inzhenernopedahohichnoi osvity. № 50-51. S. 161-167. (in Ukranian).

Obrazcov, P. I. (2003). Proektirovanie i konstruirovanie professional'no-orientirovannoj tehnologii obuchenija. [Design and construction of professionally-oriented training technology]. Orel : OGU. 94 s. (in Russian).

Petrenko, L. M. (2016). Praktyko-oriientovanyi pidkhid do formuvannia zmistu pidvyshchennia kvalifikatsii pedahohiv za dystantsiinoiu formoiu. [Practically oriented approach to forming contents of educational development of teachers by distance learning]. Metodychni zasady pidvyshchennia kvalifikatsii pedahohichnykh pratsivnykiv systemy profesiinoi osvity: zbirnyk materialiv Vseukrainskoi Internet-konferentsii. Khmelnytskyi. S. 465-469. (in Ukranian).

Pietsch, S. (2010). Begleiten und begleitet werden. Praxisnahe Fallarbeit - ein Beitrag zur Professionalisierung in der universitären Lehrerbildung. [Accompany and be accompanied. Practical case work - a contribution to professionalisation in university teacher training]. Kassel : Kassel University Press. 294 s. (in German).

Post, E.-M. (2010). Der Einsatz von handlungs-, erfahrungs- und erlebnisorientierten Methoden in der Lehrerinnen- und Lehrerfortbildung von pädagogischen Führungskräften zur Initiierung von Lernen. [The use of action, experience and experience-oriented methods in the teacher training of educational leaders to initiate learning.]. Studien zur Verknüpfung von Erfahrung, Reflexion und Transfer. Leipzig : Univ. Dass. 791 s. (in German). 
Warnek, D. (2007). Aktionsforschung und Praxisbezug in der Darf-Lehrerausbildung. [Action research and practical relevance in the Darf teacher training]. Dagmara Warneke. Kassel : Kassel Univ. Press, 2007. 599 s. (in German).

\section{Інформація про авторів:}

Хижняк Олександр Олександрович:

ORCID: http://orcid.org./ 0000-0003-17912957, аспірант кафедри загальної педагогіки i андрагогіки Полтавського національного педагогічного університету імені В. Г. Короленка, вул. Остроградського, 2, м. Полтава, Україна, 36003.

e-mail: alexkhizhniak2019@gmail.com

\section{Information about the authors:}

Khyzhniak Oleksander Oleksandrovych:

ORCID: http://orcid.org./ 0000-0003-17912957, postgraduate student of The Department of Pedagogy and Andragogy of Poltava V. G. Korolenko National Pedagogical University, 2 Ostrogradsky Street, Poltava, Ukraine, 36003.

Цитуйте цю статтю як: Хижняк О.О. Практико-орієнтований підхід у системі професійної підготовки тренера з боксу у закладах вищої освіти. Теорія та методика навчання та виховання. 2019. № 47. С. 159-168.

DOI: $10.34142 / 23128046.2019 .47 .14$

Дата надходження статті до редакції: 29.11.2019

Стаття прийнята до друку: 12.12.2019 